\title{
Inhibition of Cyclin E-Cyclin-Dependent Kinase 2 Complex Formation and Activity Is Associated with Cell Cycle Arrest and Withdrawal in Oligodendrocyte Progenitor Cells
}

\author{
Cristina A. Ghiani and Vittorio Gallo \\ Laboratory of Cellular and Molecular Neurophysiology, National Institute of Child Health and Human Development, \\ National Institutes of Health, Bethesda, Maryland 20892-4495
}

\begin{abstract}
Stimulatory and inhibitory signals regulate cell proliferation through the activity of specific enzymes that operate in distinct phases of the cell cycle. We have studied cell cycle progression, arrest, and withdrawal in the oligodendrocyte progenitor (OP) cell model system, focusing on the $G_{1}$ phase and $G_{1}-S$ transition. Not only were proliferating OPs found to display higher protein levels of cyclin E and D and cyclin-dependent kinases (cdk) 2, 4, and 6 than cells that had permanently withdrawn from the cycle, but the kinase activities of both cyclin D-cdk4/6 and cyclin E-cdk2 were also higher in dividing OPs. This was associated with a decrease in the formation of the cyclin E-cdk2 and cyclin D-cdk4/cyclin D-cdk6 complexes in differentiated oligodendrocytes that had permanently withdrawn from the cell cycle. Reversible cell cycle arrest in $G_{1}$ induced by glutamatergic and $\beta$-adrenergic receptor activation
\end{abstract}

or cell depolarization, however, did not modify cyclin E and cdk2 protein expression compared with proliferating OPs. Instead, these agents caused a selective decrease in cdk2 activity and an impairment of cyclin E-cdk2 complex formation. Although cyclin D protein levels were higher than in proliferating cells, cyclin D-associated kinase activity was not modified in $\mathrm{G}_{1}$-arrested OPs. Analysis in corpus callosum in vivo showed that cyclin E-cdk2 activity increased between postnatal days 3 and 15 and decreased between postnatal days 15 and 30. Our results indicate that the cyclin $\mathrm{E}-\mathrm{cdk} 2$ complex is a major regulator of OP cell cycle progression and that the cdks involved in reversible cell cycle arrest are distinct from those implicated in permanent cell cycle withdrawal.

Key words: glia; development; cell proliferation; $G_{1}$ phase; cyclin D; cyclin-dependent kinase 4
Our understanding of how neural cell proliferation is regulated during development is based on elucidating the network of molecular interactions that control cell cycle progression and arrest. Multiple proteins are responsible for coordinating advancement through each phase of the cycle, particularly $G_{1}$ phase and its restriction points, when a cell is committed to progression to $\mathrm{S}$ phase or is withdrawn from the cycle (Pardee, 1989; Hunter, 1993; Sherr, 1994; Weinberg, 1995; Elledge, 1996). The formation of two major protein complexes and their associated kinase activities are required for $\mathrm{G}_{1}-\mathrm{S}$ progression: cyclin $\mathrm{D}$-cyclindependent kinase (cdk) 4/6 is active in early $G_{1}$ phase, whereas cyclin $\mathrm{E}-\mathrm{cdk} 2$ is required for entry into $\mathrm{S}$ phase (Reed et al., 1994; Morgan, 1995; Sherr, 1995). Cyclin-dependent kinase inhibitors (cdkis) (Sherr and Roberts, 1995; Martin-Castellanos and Moreno, 1997) negatively regulate the activity of these complexes.

In the developing brain, neural precursor cell division is not

\footnotetext{
Received June 1, 2000; revised Oct. 5, 2000; accepted Nov. 9, 2000.

We thank Xiaoqing Yuan and Stefania Porta for their help in the preparation of corpus callosum tissue samples. We are grateful to Franca Cambi and Esteban Dell'Angelica for sharing their expertise with immunoprecipitation and kinase assays and for helpful discussion. We are thankful to Beth Stevens for stimulating discussion. We thank Li-Jin Chew, Douglas Fields, Chris McBain, and Beth Stevens for critically reading this manuscript.

Correspondence should be addressed to Dr. Vittorio Gallo, Laboratory of Cellular and Molecular Neurophysiology, National Institute of Child Health and Human Development, National Institutes of Health, Building 49, Room 5A-78, Bethesda, MD 20892-4495. E-mail: vgallo@helix.nih.gov.

Dr. Ghiani's present address: Department of Psychiatry and Biobehavioral Sciences, University of California at Los Angeles, Brain Research Institute, Gonda Building 3524, 695 Charles E. Young Drive South, Los Angeles, CA 90095-1761. Copyright (C) 2001 Society for Neuroscience $0270-6474 / 01 / 211274-09 \$ 15.00 / 0$
}

only intrinsically driven but also responsive to the extracellular environment (Purves, 1988; Raff, 1996; Ross, 1996; Edlund and Jessell, 1999). Soluble cellular factors modulate neural cell proliferation by influencing progression through $\mathrm{G}_{1}$ phase (Ross, 1996). Axonal inputs prolong cell cycle kinetics or promote $G_{1}-S$ transition in neural precursors (Selleck et al., 1992; Gong and Shipley, 1995). Conversely, cell cycle withdrawal in $\mathrm{G}_{0}-\mathrm{G}_{1}$ is induced by thyroid hormone and peptide factors (Pedram et al., 1998; Perez-Juste and Aranda, 1999).

Oligodendrocytes originate from progenitor cells (OPs) that proliferate, migrate, and differentiate postnatally (McCarthy and deVellis, 1980; Raff et al., 1983; Reynolds and Wilkin, 1988; Gard and Pfeiffer, 1990; Levison and Goldman, 1993; Luskin and McDermott, 1994; Zerlin et al., 1995). Previous studies in culture and in vivo indicated that the cdkis $\mathrm{p} 27^{\mathrm{Kip} 1}$ and $\mathrm{p} 21^{\mathrm{Cip} 1}$ are important regulators of OP cell proliferation during development (Durand et al., 1997, 1998; Casaccia-Bonnefil et al., 1997,1999; Tang et al., 1998; Ghiani et al., 1999a,b). The levels of these cdkis increase in OP cells either during permanent cell cycle withdrawal and differentiation or during reversible cell cycle arrest in $\mathrm{G}_{1}$ caused by neuronal signals (Durand et al., 1997, 1998; Casaccia-Bonnefil et al., 1997,1999; Ghiani et al., 1999a,b). In view of the known negative regulatory effects of $\mathrm{p} 27^{\mathrm{Kip} 1}$ and p $21^{\mathrm{Cip} 1}$ on the cyclin D-cdk4/6 and cyclin E-cdk 2 complexes (Sherr and Roberts, 1995), it can be concluded that regulation of $\mathrm{G}_{1}$ phase progression is crucial for OP cell proliferation.

In the present study, we investigated neural cell cycle regulation in the OP cell model system. We analyzed the molecular mechanisms of cell cycle withdrawal and arrest in OPs and identified some of the proteins affected by neuronal signals. We 
focused on cyclin-cdks involved in $\mathrm{G}_{1}-\mathrm{S}$ transition and analyzed the formation of the cyclin E-cdk2 and cyclin D-cdk4/6 complexes as one of the mechanisms of regulation of the activity of these cdks (Morgan, 1995). Our results indicate that the formation of the cyclin E-cdk2 complex and its activity play a crucial role in both processes and that cyclin E-cdk2 activity is downregulated in adult white matter.

\section{MATERIALS AND METHODS}

Materials. Platelet-derived growth factor (PDGF) (human, AB, and heterodimer forms) and basic fibroblast growth factor (bFGF) (human) were both from Upstate Biotechnology (Lake Placid, NY). L-3,3',5triiodothyronine sodium salt was from Calbiochem (La Jolla, CA). Isoproterenol, kainic acid, tetraethylammonium chloride (TEA), and veratridine were all from Sigma (St. Louis, MO). Anti-cyclin D antibodies (anti-human and rabbit polyclonal) were from Upstate Biotechnology. Anti-cyclin E (rabbit polyclonal, M-20), anti-cyclin D1 (mouse monoclonal, 72-13G), anti-cdk2 (rabbit polyclonal, M2, or mouse monoclonal, D-12), anti-cdk4 (rabbit polyclonal, C-22), and anti-cdk6 (rabbit polyclonal, C-21) antibodies were all from Santa Cruz Biotechnology (Santa Cruz, CA).

Cell cultures. Purified cortical OP cell cultures were prepared as described previously (Gallo et al., 1996; Ghiani et al., 1999a) from embryonic day 20 Sprague Dawley rats. The animals were killed following the National Institutes of Health Animal Welfare guidelines. OP cells were plated onto poly-D-ornithine-coated plates $(0.1 \mathrm{mg} / \mathrm{ml})$ and cultured in DMEM-N1 biotin-containing medium. In cells cultured with PDGF (10 $\mathrm{ng} / \mathrm{ml}$ ), the growth factor was added to the culture medium $2 \mathrm{hr}$ after plating for $48 \mathrm{hr}$. To differentiate OP cells into preoligodendrocytes or oligodendrocytes, OPs were cultured for $2 \mathrm{~d}$ in PDGF $(10 \mathrm{ng} / \mathrm{ml})$ and for 3 additional days in DMEM-N1 biotin-containing medium plus $0.5 \%$ fetal bovine serum (FBS) or in DMEM-N1 medium containing L-3,3',5triiodothyronine sodium salt (T3) $(100 \mathrm{ng} / \mathrm{ml})$. Previously, we demonstrated that in PDGF-treated cultures $100 \%$ of the cells expressed nestin and $>90 \%$ of the nestin ${ }^{+}$cells were $\mathrm{GD}^{+}$or $\mathrm{A} 2 \mathrm{~B} 5^{+}$(Gallo and Armstrong, 1995; Gallo et al., 1996). Less than 5\% of O4 ${ }^{+}$cells and no $\mathrm{O} 1^{+}$cells were found in these cultures (Gallo and Armstrong, 1995; Gallo et al., 1996). In cultures maintained in N1 medium plus $0.5 \%$ FBS, $83.6 \pm 1.6 \%$ of the cells were $\mathrm{O}^{+}(n=10$ microscopic fields; total cells counted, 1917), and $7.7 \pm 0.7 \%$ of the total cells were $\mathrm{O}^{+}(n=10$ microscopic fields; total cells counted, 2235). In cultures treated with T3 hormone, $97.3 \pm 0.2 \%$ of the total cells were $\mathrm{O}^{+}{ }^{+}(n=10$ microscopic fields; total cells counted, 5332).

Immunoprecipitation and Western blot. For the immunoprecipitation of cyclin D and cyclin E in OP cultures, $2 \times 10^{6}$ cells were washed twice and harvested in ice-cold PBS. The cell pellets were resuspended in $100 \mu \mathrm{l}$ of sample buffer [50 mm HEPES, pH 7.4, $150 \mathrm{~mm} \mathrm{NaCl,} 1$ mm EDTA, 2.5 mM EGTA, $1 \%$ Nonidet P-40 (NP-40), 1 mM Na $\mathrm{VO}_{4}, 4 \mu \mathrm{M} \mathrm{NaF}, 10$ $\mu \mathrm{g} / \mathrm{ml}$ leupeptin, $10 \mu \mathrm{g} / \mathrm{ml}$ aprotinin, $10 \mu \mathrm{g} / \mathrm{ml}$ pepstatin, and $1 \mathrm{~mm}$ 4-(2-aminoethyl)benzenesulfonyl fluoride (AEBSF)] and lysed for 45 min on ice, followed by a brief sonication. The lysate was clarified by centrifugation at $12,000 \mathrm{rpm}$ for $5 \mathrm{~min}$, and the supernatant was collected. An aliquot was taken for protein determination using the Pierce (Rockford, IL) BCA* protein assay kit. Cell extracts $(200 \mu \mathrm{g})$ were then incubated for $2 \mathrm{hr}$ at $4^{\circ} \mathrm{C}$ with saturating concentrations of monoclonal or polyclonal antibodies. The immune complexes were collected by incubating with protein A- or G-agarose (20 $\mu \mathrm{l}$; Santa Cruz Biotechnology) for polyclonal or monoclonal antibodies, respectively. The beads were then washed four times in washing buffer (50 mM HEPES, pH 7.4, $150 \mathrm{~mm}$ $\mathrm{NaCl}, 1$ mm EDTA, 2.5 mм EGTA, 0.5\% NP-40, $1 \mathrm{~mm} \mathrm{Na}_{3} \mathrm{VO}_{4}, 4 \mu \mathrm{M}$ $\mathrm{NaF}, 10 \mu \mathrm{g} / \mathrm{ml}$ leupeptin, $10 \mu \mathrm{g} / \mathrm{ml}$ aprotinin, $10 \mu \mathrm{g} / \mathrm{ml}$ pepstatin, and 1 mM AEBSF) and once in $1 \times$ PBS. Samples were resolved on $4-20 \%$ mini-SDS polyacrylamide gel and transferred to Immobilon polyvinylidene difluoride (PVDF) membranes (Millipore, Bedford, MA). Blots were blocked with $5 \%$ nonfat dry milk in PBS-T $\left(17 \mathrm{~mm} \mathrm{KH}_{2} \mathrm{PO}_{4}, 50 \mathrm{~mm}\right.$ $\mathrm{Na}_{2} \mathrm{HPO}_{4}, 1.5 \mathrm{~mm} \mathrm{NaCl}, \mathrm{pH} \mathrm{7.4}$, and $0.05 \%$ Tween 20) for $1 \mathrm{hr}$ at room temperature and then incubated overnight at $4{ }^{\circ} \mathrm{C}$ in PBS-T plus $5 \%$ nonfat dry milk containing antibodies. Protein bands were detected using the Amersham ECL kit (Amersham Pharmacia Biotech, Piscataway, NJ), with horse-radish peroxidase-conjugated secondary goat anti-rabbit or goat anti-mouse antibodies (Transduction Laboratories, Lexington, KY). Relative intensities of the protein bands were quantified by scanning densitometry (Scanwizard Plug-in; Microtek, Redondo Beach, CA).
For Western blotting, 20-25 $\mu \mathrm{g}$ of the cell extracts were resolved on a 4-20\% mini-SDS polyacrylamide gel and transferred to Immobilon PVDF membranes. Equal protein loading was verified by ponceau $\mathrm{S}$ solution (Sigma) reversible staining of the blots. Blots were processed as reported previously (Ghiani et al., 1999a,b).

Corpus callosum or optic nerve from postnatal day 3 (P3) to P30 rats was homogenized in 100-300 $\mu \mathrm{l}$ of sample buffer (50 mM HEPES, $\mathrm{pH}$ 7.4, $150 \mathrm{~mm} \mathrm{NaCl}, 1 \mathrm{~mm}$ EDTA, $2.5 \mathrm{~mm}$ EGTA, $1 \%$ NP-40, $1 \mathrm{~mm}$ $\mathrm{Na}_{3} \mathrm{VO}_{4}, 4 \mu \mathrm{M} \mathrm{NaF}, 10 \mu \mathrm{g} / \mathrm{ml}$ leupeptin, $10 \mu \mathrm{g} / \mathrm{ml}$ aprotinin, $10 \mu \mathrm{g} / \mathrm{ml}$ pepstatin, and $1 \mathrm{~mm}$ AEBSF), followed by $30 \mathrm{~min}$ incubation on ice. The lysate was clarified by centrifugation at $12,000 \mathrm{rpm}$ for $5 \mathrm{~min}$, and the supernatant was collected. An aliquot was taken for protein determination using the Pierce $\mathrm{BCA}^{*}$ protein assay kit. Tissue extract $(30 \mu \mathrm{g})$ were resolved on a $4-20 \%$ mini-SDS polyacrylamide gel and processed as described above for Western blot.

Kinase assays. Cyclin D-associated kinase activity was determined as reported previously (Matsushime et al., 1994) with minor modifications. OP cells were cultured in $35 \mathrm{~mm}$ dishes and lysed in $250 \mu \mathrm{l}$ of lysis buffer (50 mm HEPES, pH 7.4, $150 \mathrm{~mm} \mathrm{NaCl}, 1$ mM EDTA, $2.5 \mathrm{~mm}$ EGTA, $0.5 \% \mathrm{NP}-40,10 \% \mathrm{Na}_{4} \mathrm{P}_{2} \mathrm{O}_{4}, 1 \mathrm{~mm} \mathrm{Na} \mathrm{VO}_{4}, 4 \mu \mathrm{M} \mathrm{NaF}, 10 \mu \mathrm{g} / \mathrm{ml}$ leupeptin, $10 \mu \mathrm{g} / \mathrm{ml}$ aprotinin, $10 \mu \mathrm{g} / \mathrm{ml}$ pepstatin, and $1 \mathrm{~mm}$ AEBSF). Cell lysates $(100 \mu \mathrm{g})$ were immunoprecipitated with a saturating concentration of a mouse monoclonal antibody to cyclin D1 (72-13G; Santa Cruz Biotechnology) for $2 \mathrm{hr}$ at $4^{\circ} \mathrm{C}$. The immune complexes were collected on $20 \mu \mathrm{l}$ of protein G-agarose (Santa Cruz Biotechnology). To measure cdk2-associated activity, cells or tissues were lysed in $50 \mathrm{mM}$ HEPES, $\mathrm{pH}$ 7.4, $250 \mathrm{~mm} \mathrm{NaCl}, 5 \mathrm{~mm}$ EDTA, 0.5\% NP-40, $10 \% \mathrm{Na}_{4} \mathrm{P}_{2} \mathrm{O}_{4}, 1 \mathrm{~mm}$ $\mathrm{Na}_{3} \mathrm{VO}_{4}, 4 \mu \mathrm{M} \mathrm{NaF}, 10 \mu \mathrm{g} / \mathrm{ml}$ leupeptin, $10 \mu \mathrm{g} / \mathrm{ml}$ aprotinin, $10 \mu \mathrm{g} / \mathrm{ml}$ pepstatin, and $1 \mathrm{~mm}$ AEBSF. Cell or tissue lysates $(50 \mu \mathrm{g})$ were then immunoprecipitated with a rabbit polyclonal antibody against cdk2 (M2; Santa Cruz Biotechnology) for $2 \mathrm{hr}$ at $4^{\circ} \mathrm{C}$ plus $20 \mu \mathrm{l}$ of protein A-agarose (Santa Cruz Biotechnology). The beads were washed three times with $500 \mu \mathrm{l}$ of lysis buffer and two additional times with $1 \times$ kinase assay buffer (50 mM HEPES, pH 7.4, $50 \mathrm{~mm} \mathrm{MgCl}_{2}$, and $1 \mathrm{~mm} \mathrm{DTT}$ ) before performing the kinase reaction. Kinase reaction mixtures $(20 \mu \mathrm{l})$ contained $10 \mu \mathrm{g}$ of glutathione $S$-transferase-retinoblastoma protein $(\mathrm{pRb})$ (Santa Cruz Biotechnology) or $2 \mu \mathrm{g}$ of histone H1 (Upstate Biotechnology) as substrates, $20 \mu \mathrm{M}$ ATP, and $2 \mu \mathrm{Ci}\left[\gamma^{-}{ }^{32} \mathrm{P}\right] \mathrm{ATP}$ (New England Nuclear, Boston, MA). Reactions were stopped by adding $20 \mu \mathrm{l}$ of $2 \times$ SDS loading buffer and heating at $95^{\circ} \mathrm{C}$ for $3 \mathrm{~min}$. Labeled proteins were resolved on $4-20 \%$ mini-SDS polyacrylamide gels, which were dried. Phosphorylated $\mathrm{pRb}$ or histone $\mathrm{H} 1$ bands were visualized and quantitated by PhosphorImager (Molecular Dynamics, Sunnyvale, CA).

\section{RESULTS Cell cycle withdrawal and arrest differentially affect
cyclin E- and cyclin D-associated kinase activities}

OPs were cultured for 2-3 d either in PDGF or in the absence of mitogenic factors, under conditions that promoted their lineage progression into preoligodendrocytes (N1 plus $0.5 \%$ FBS) or differentiated oligodendrocytes (N1 plus T3 hormone). In parallel experiments, we observed that OPs cultured under either of these conditions and then exposed to PDGF did not incorporate bromodeoxyuridine (C. A Ghiani and V. Gallo, data not shown), indicating that these cells had permanently withdrawn from the cycle.

In agreement with previous studies (Casaccia-Bonnefil et al., 1997; Tikoo et al., 1997), the expression of both the regulatory subunits cyclin E and cyclin D was strongly reduced in cells that had withdrawn from the cycle (culture conditions, N1 with or without T3) compared with cells cultured with PDGF (Fig. 1 $A$, Table 1). The levels of the cdks partners of these cyclins, cdk2 and cdk4/6, were also significantly decreased in OPs cultured in the absence of mitogens (Fig. 1 $A$, Table 1) (Casaccia-Bonnefil et al., 1997; Tikoo et al., 1997). Conversely, agents that caused reversible $\mathrm{G}_{1}$ arrest and inhibited OP cell proliferation (Ghiani et al., 1999a,b) affected only cyclin D. A $48 \mathrm{hr}$ treatment with the glutamate receptor (GluR) agonist kainate, the $\beta$-adrenergic receptor $\left(\beta\right.$-AR) agonist isoproterenol, the $\mathrm{K}^{+}$channel blocker 
A

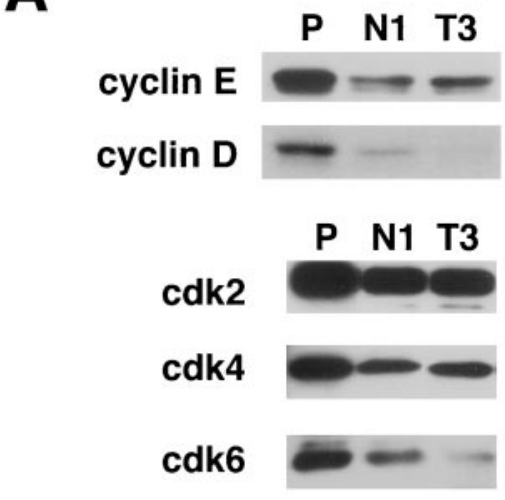

B
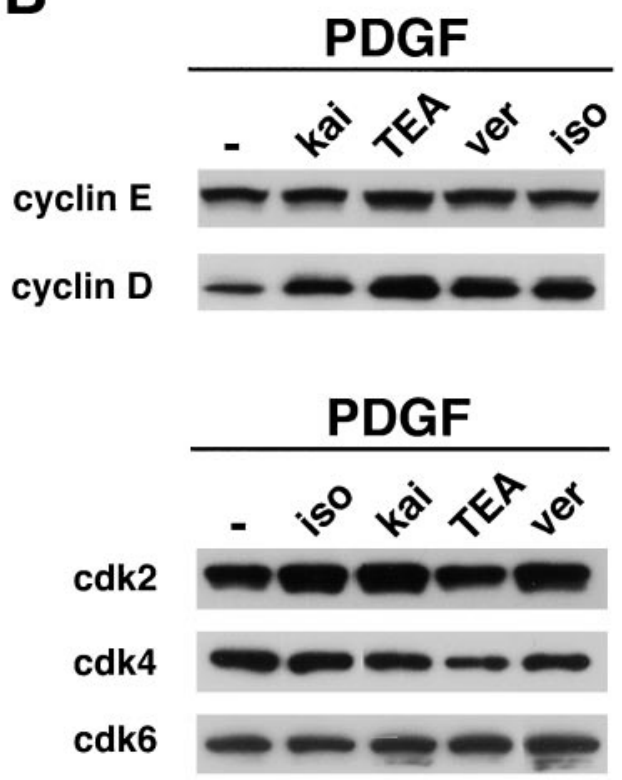

Figure 1. The protein levels of $\mathrm{G}_{1}-\mathrm{S}$ cdks and cyclins are modified during permanent cell cycle withdrawal and reversible $\mathrm{G}_{1}$ arrest. $A$, Expression of $\mathrm{G}_{1}-\mathrm{S}$ cdks and cyclins is downregulated in postmitotic oligodendrocytes compared with proliferating OPs. OP cells were cultured for $2 \mathrm{~d}$ in PDGF (10 ng/ml), followed by $3 \mathrm{~d}$ in N1 plus $0.5 \%$ FBS medium or N1 plus T3 $(100 \mathrm{ng} / \mathrm{ml})$ hormone medium to promote differentiation to oligodendrocytes. Proliferating OPs were harvested after 48 hr. Western blot analysis was performed by loading $20-25 \mu \mathrm{g}$ of cell lysates for each sample. $B$, Neurotransmitter receptor activation, blockage of $\mathrm{K}^{+}$channels, and cell depolarization do not affect cdk protein levels. OP cells were cultured for $48 \mathrm{hr}$ with PDGF in the presence or in the absence of the GluR agonist kainate $($ kai; $100 \mu \mathrm{M})$, the $\mathrm{K}^{+}$channel blocker TEA $(5 \mathrm{mM})$, the $\mathrm{Na}^{+}$channel opener veratridine $(v e r ; 30 \mu \mathrm{M})$, or the $\beta$-AR agonist isoproterenol (iso; $50 \mu \mathrm{M}$ ). A summary of quantitative changes in cdks and cyclins is shown in Table 1.

TEA, or the $\mathrm{Na}^{+}$channel activator veratridine did not significantly modify cyclin E, cdk2, cdk4, and cdk6 protein levels (Fig. $1 B$ ). On the other hand, all of these agents significantly increased cyclin D protein levels (Fig. 1B, Table 1).

Permanent cell cycle withdrawal or reversible arrest in $G_{1}$ phase are often attributable to a reduction in the activity of the cyclin-cdk complexes that promote cell cycle progression through this phase, i.e., cyclin E-cdk2 and cyclin D-cdk4/6. Cyclin D-associated activity was measured by its ability to phosphorylate the endogenous substrate $\mathrm{pRb}$. In OP cells that had withdrawn from the cycle, the activity of cyclin D-cdk4/6 com- plexes was reduced by $30 \%$ compared with PDGF-treated cells (Fig. 2). In dividing OP cells, none of the antiproliferative agents (isoproterenol, kainate, TEA, or veratridine) affected cyclin D-associated kinase activity (Fig. 2). These results suggest that different mechanisms mediate permanent cell cycle withdrawal or cell cycle arrest in $\mathrm{G}_{1}$ phase.

The cyclin E-cdk2 complex is required for the progression from $\mathrm{G}_{1}$ to $\mathrm{S}$ phase. Figure 3 shows that the activity of cdk 2 was primarily reduced in OP cells that had irreversibly withdrawn from the cycle compared with proliferating OP cells cultured with PDGF (76 and 83\% decrease in cells cultured in N1 and T3, respectively). A decrease of $50-60 \%$ in cdk2 kinase activity was also observed after treatment of OP cells with GluR or $\beta$-AR agonists, the $\mathrm{K}^{+}$channel blocker TEA, or depolarization with veratridine (Fig. 3).

The time course of regulation of cyclin E-cdk2 activity is consistent with cell cycle withdrawal or arrest in $\mathrm{G}_{1}$ phase

The time course of cdk2 activity regulation was analyzed under conditions that caused cell cycle withdrawal or cell cycle arrest to demonstrate that activity of this cdk was primarily associated with $\mathrm{G}_{1}$ phase. In OP cells cultured with PDGF for $2 \mathrm{~d}$, we observed that cdk2 activity dropped by $\sim 50 \%$ within the first $6 \mathrm{hr}$ after growth factor removal and to very low levels within $18 \mathrm{hr}$ after PDGF withdrawal (Fig. 4A).

In a complementary set of experiments, we analyzed the time course of stimulation of cdk2 activity by two mitogenic factors. Figure $4 B$ shows that both PDGF and bFGF significantly increased cdk 2 activity within $18 \mathrm{hr}$. In OPs cultured with PDGF, cdk2 activity continued to increase up to $48 \mathrm{hr}$, whereas in bFGF-treated cells, it reached a plateau between 18 and $24 \mathrm{hr}$ and then decreased (Fig. 4B). These results indicate the following: (1) the 6-18 hr time window of OP cell cycle is critical for regulation of cdk2 activity and cell cycle progression, and (2) cdk2 activity plays an important role in progression through $\mathrm{G}_{1}$ phase.

This was confirmed by the finding that a similar time course of cdk2 activity regulation was observed in OP cells cultured with PDGF and agents that caused reversible $\mathrm{G}_{1}$ arrest (Ghiani et al., 1999a,b). Figure 5 shows that kainate, isoproterenol, and TEA prevented the increase in cdk2 activity observed in PDGF-treated cells between 6 and $18 \mathrm{hr}$. After $48 \mathrm{hr}$ treatment, cdk 2 activity was high in PDGF-treated cells but barely detectable in cells treated with PDGF and the agents that caused $\mathrm{G}_{1}$-arrest (Fig. $5 \mathrm{~A}$ ).

The decrease in cyclin E-cdk2 activity is attributable to inhibition of cyclin E-cdk2 complex formation

Inhibition of cdk2 activity could involve a decrease in cyclin E-cdk2 complex formation (Koff et al., 1993). To test this hypothesis, we determined the relative amount of cdk2 associated to cyclin $\mathrm{E}$ in OP cell extracts by immunoprecipitation of the complex with an anti-cyclin $\mathrm{E}$ antibody, followed by Western blot analysis of the immunoprecipitate with an anti-cdk2 antibody. Figure $6 A$ shows that permanent OP cell cycle withdrawal caused a large decrease in the amount of cyclin E-associated cdk2 (OPs cultured in N1). Furthermore, T3 hormone treatment of the cells almost completely prevented the association of cdk2 to cyclin $\mathrm{E}$ (Fig. $6 A$ ). All of the agents that caused reversible $\mathrm{G}_{1}$ arrest in OP cells strongly impaired cyclin E-cdk2 complex formation (Fig. 6A).

Interestingly, formation of the cyclin $\mathrm{D}$-cdk4 complex in OP cells was primarily impaired by culture conditions that promoted permanent cell cycle withdrawal, but not by agents that caused 
Table 1. Expression of cyclins and cyclin-dependent kinases in oligodendrocyte progenitor cells changes during development in culture and after treatment with agents that cause cell cycle arrest in G1 phase

Relative protein levels (\% of PDGF-treated controls)

\begin{tabular}{|c|c|c|c|c|c|c|}
\hline \multirow[b]{2}{*}{ Culture conditions } & \multicolumn{2}{|c|}{ Cell cycle withdrawal } & \multicolumn{4}{|c|}{ Cell cycle arrest } \\
\hline & $\mathrm{N} 1$ & $\mathrm{~T} 3$ & iso & kai & TEA & ver \\
\hline Cyclin D & $40 \pm 10^{*}$ & $41 \pm 8^{*}$ & $166 \pm 21^{*}$ & $198 \pm 8.0^{* * * *}$ & $144 \pm 12^{*}$ & $177 \pm 9.2^{*}$ \\
\hline Cyclin E & $15 \pm 4 * *$ & $44 \pm 16^{* * *}$ & $117 \pm 9.9$ & $104 \pm 2.6$ & $108 \pm 20$ & $114 \pm 16$ \\
\hline $\mathrm{Cdk} 2$ & $78 \pm 6.7^{*}$ & $69 \pm 7.8^{*}$ & $112 \pm 5.0$ & $98 \pm 5.3$ & $81 \pm 9.5$ & $94 \pm 6.0$ \\
\hline $\mathrm{Cdk} 4$ & $79 \pm 8.1^{*}$ & $65 \pm 4.2^{* * *}$ & $106 \pm 2.9$ & $106 \pm 9.5$ & $80 \pm 15$ & $90 \pm 2.5$ \\
\hline Cdk6 & $58 \pm 15^{*}$ & $20 \pm 7.9^{* * *}$ & $105 \pm 6.5$ & $125 \pm 20$ & $121 \pm 18$ & $127 \pm 25$ \\
\hline
\end{tabular}

OP cells were cultured under conditions that caused permanent cell cycle withdrawal ( $2 \mathrm{~d}$ in PDGF, followed by $3 \mathrm{~d}$ in N1 plus $0.5 \%$ FBS medium or N1 plus T3 hormone medium) or reversible cell cycle arrest in G1 phase [2 d in PDGF, in the presence or in the absence of the $\beta$-AR agonist isoproterenol (iso; $50 \mu \mathrm{M}$ ), the GluR agonist kainate (kai; $100 \mu \mathrm{M}$ ), the $\mathrm{K}^{+}$ channel blocker TEA $(5 \mathrm{mM})$, or the $\mathrm{Na}^{+}$channel opener veratridine (ver; $\left.30 \mu \mathrm{M}\right)$ ]. Western blot analysis was performed by loading 20-25 $\mu \mathrm{g}$ of cell lysates for each sample. Values were determined by densitometric analysis of autoradiographs from Western blots and are expressed as ratios of samples treated with PDGF alone. The mean \pm SEM of three to five separate experiments is shown for each treatment; ${ }^{*} p<0.05,{ }^{*} p<0.01$, ***p $p<0.005$, and $* * * p<0.001$ compared with PDGF-treated cells (Student's $t$ test).

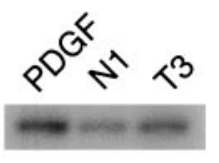

PDGF
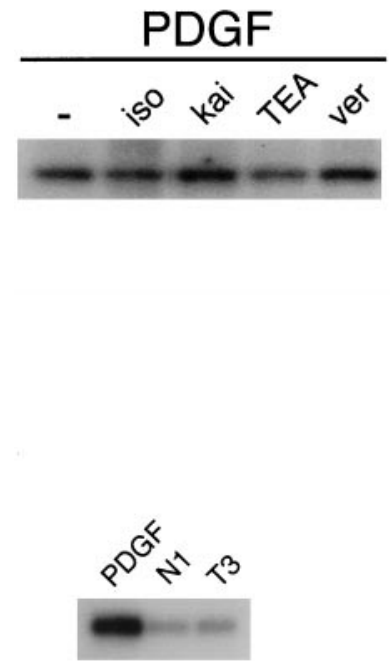

PDGF

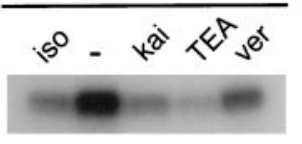

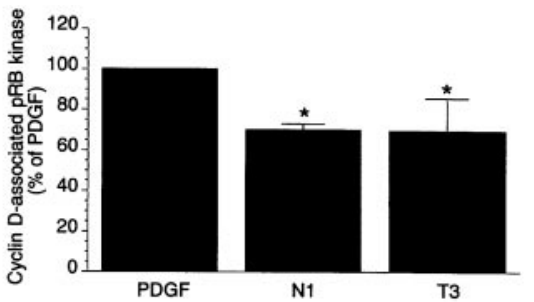

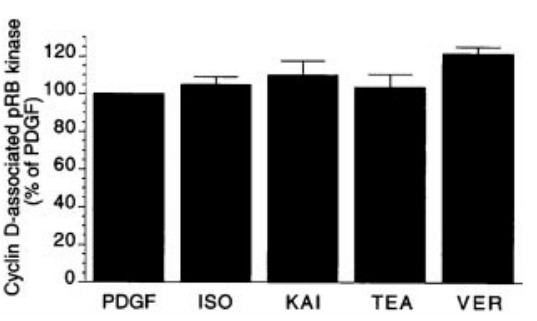

Figure 2. Permanent cell cycle withdrawal and reversible $\mathrm{G}_{1}$ arrest differentially affect cyclin D-associated kinase activity. In the top panel, OPs were cultured for $2 \mathrm{~d}$ in PDGF and then for $3 \mathrm{~d}$ in N1 plus $0.5 \%$ FBS medium or N1 plus T3 (100 $\mathrm{ng} / \mathrm{ml}$ ) hormone medium. In the bottom panel, cells were cultured for $2 \mathrm{~d}$ with PDGF in the presence or in the absence of the $\beta$-AR agonist isoproterenol (iso; $50 \mu \mathrm{M})$, the GluR agonist kainate (kai; $100 \mu \mathrm{M})$, the $\mathrm{K}^{+}$channel blocker TEA $(5 \mathrm{mM})$, or the $\mathrm{Na}^{+}$channel opener veratridine $($ver; $30 \mu \mathrm{M})$. Cyclin D-associated kinase activity was determined after immunoprecipitation of $100 \mu \mathrm{g}$ of total cellular protein extracts with anti-cyclin $\mathrm{D}$ antibodies and by using $\mathrm{pRb}$ as a substrate. Data were obtained after PhosphorImager analysis of the autoradiographs and are expressed as percentage of cyclin D-associated kinase activity found in cells cultured in PDGF. Averages of four separate experiments are shown. Error bars are SEM. ${ }^{*} p<0.05$ versus PDGF (Student's $t$ test).
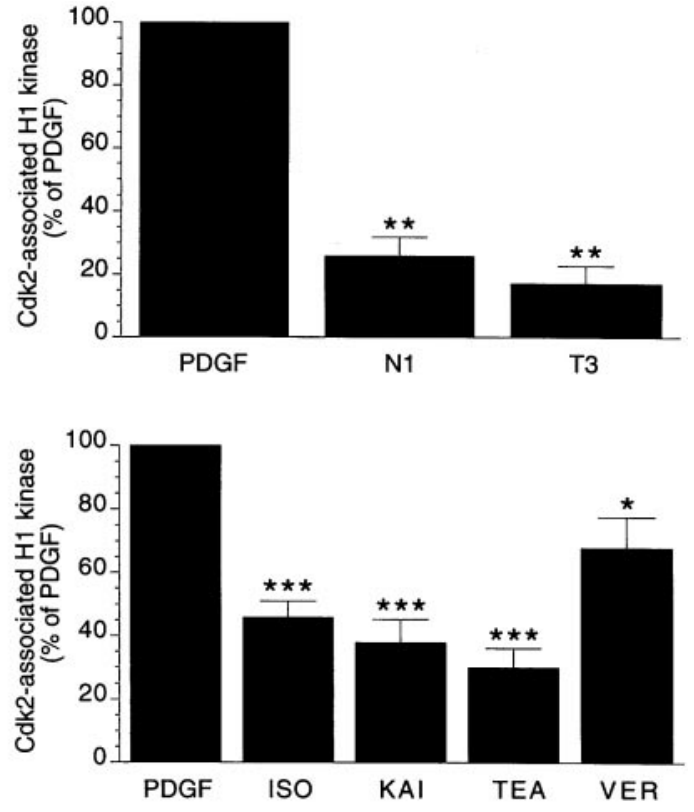

Figure 3. Permanent cell cycle withdrawal and reversible $\mathrm{G}_{1}$ arrest strongly decrease cyclin E-cyclindependent kinase 2 activity. In the top panel, OPs were cultured for $2 \mathrm{~d}$ in PDGF and then for $3 \mathrm{~d}$ in N1 plus $0.5 \%$ FBS medium or N1 plus T3 $(100 \mathrm{ng} / \mathrm{ml})$ hormone medium. In the bottom panel, cells were cultured for $2 \mathrm{~d}$ with PDGF in the presence or in the absence of the $\beta$-AR agonist isoproterenol (iso; $50 \mu \mathrm{M}$ ), the GluR agonist kainate $(\mathrm{kai} ; 100 \mu \mathrm{M})$, the $\mathrm{K}^{+}$channel blocker TEA (5 $\mathrm{mM}$ ), or the $\mathrm{Na}^{+}$channel opener veratridine (ver; $30 \mu \mathrm{M}$ ). Cdk2-associated kinase activity was determined after immunoprecipitation of $50 \mu \mathrm{g}$ of total cellular protein extracts with anti-cdk2 antibodies and by using histone H1 as a substrate. Data were obtained after PhosphorImager analysis of the autoradiographs and are expressed as percentage of cdk2-associated kinase activity found in cells cultured in PDGF. Averages of four (top) and eight (bottom) separate experiments are shown. Error bars are SEM. ${ }^{*} p<0.05,{ }^{* *} p<0.001$, and ${ }^{* * *} p<0.0001$ versus PDGF (Student's $t$ test). 
A

Figure 4. The time course of regulation of cyclin $\mathrm{E}-\mathrm{cdk} 2$ activity is consistent with permanent cell cycle withdrawal in $\mathrm{G}_{1}$ phase. $A$, OPs were cultured for $2 \mathrm{~d}$ in PDGF and then placed in $\mathrm{N} 1$ plus $0.5 \%$ FBS medium or N1 plus T3 $(100 \mathrm{ng} / \mathrm{ml})$ hormone medium for up to an additional $48 \mathrm{hr}$. OP cells were harvested at different times after changing from the PDGF-containing culture medium to the mitogen-free medium. $B$, Newly plated OPs were cultured for a total of $2 \mathrm{~d}$ in PDGF or in bFGF (both $10 \mathrm{ng} / \mathrm{ml}$ ). OP cells were harvested at different times after adding PDGF or bFGF to the culture medium. Cdk2-associated kinase activity was determined after immunoprecipitation of 50 $\mu \mathrm{g}$ of total cellular protein extracts with anti-cdk2 antibodies and by using histone $\mathrm{H} 1$ as a substrate. The plots represent relative levels of cdk2associated activity, obtained by PhosphorImager analysis of the autoradiographs shown on the left. Both $A$ and $B$ show representative experiments that were replicated twice with similar results.

B
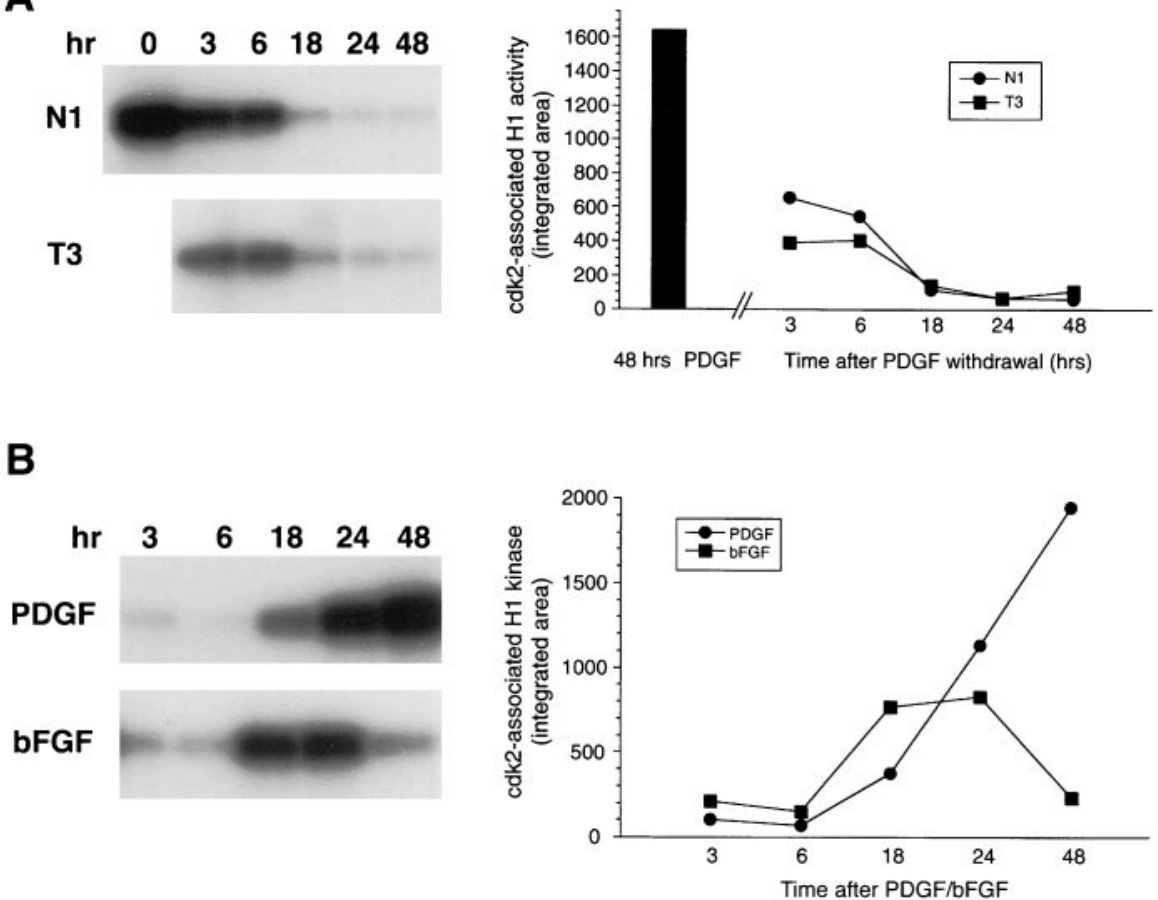

reversible $\mathrm{G}_{1}$ arrest (Fig. $6 B$ ). Conversely, all of these agents had opposite effects, i.e., increased cyclin D-cdk4 complex formation (Fig. 6B). In addition, formation of the cyclin D-cdk6 complex in OPs was decreased only under conditions that promoted cell cycle withdrawal and maturation to the $\mathrm{O}^{+}$stage (Fig. 6C, T3 lane).

\section{Cyclin E and cdk2 levels and cyclin E-cdk2 activity decrease in corpus callosum during development in vivo}

To correlate our findings on the expression and regulation of cell cycle protein in cultured OP cells with OP development in vivo, we analyzed the $\mathrm{G}_{1}-\mathrm{S}$ cyclin and cdk proteins and their activity in corpus callosum during postnatal development. Figure $7 A$ shows that cdk2 and cyclin E levels were rather constant before P15 and sharply decreased between P15 and P30. Cyclin D levels did not significantly change before P15 and decreased between P15 and P30. Both cdk4 and cdk6 displayed a significant decrease between P10 and P30. Finally, cyclin E-cdk2 activity progressively increased between P3 and P15 and then decreased between P15 and P30 (Fig. 7B).

Similar results were also obtained when $\mathrm{G}_{1}-\mathrm{S}$ cyclin and cdk levels were analyzed in postnatal optic nerve tissue by Western blot (data not shown). Cyclin E and cyclin D levels decreased by $\sim 50 \%$ between P3 and P15 and were barely detectable by P30. Relative to the levels measured at P3, cdk2 decreased by $17 \%$ between P10 and P15 and by $75 \%$ between P15 and P30. Cdk4 levels were unchanged between P3 and P15 but decreased by $50 \%$ between P15 and P30. Finally, cdk6 levels sharply decreased by $70-80 \%$ between $\mathrm{P} 3$ and P15 and were barely detectable by P30.

In conclusion, the analysis in white matter tissue indicates that, consistent with the results obtained in cultured cells, cdk2 and cyclin E as well as cyclin E-cdk2 activity decrease during oligodendrocyte maturation in vivo. Furthermore, similar to cultured OPs, cdk4 and cdk6 levels decreased after oligodendrocyte differentiation in vivo.

\section{DISCUSSION}

During development, proliferating OP cells must undergo cell cycle arrest and withdrawal before they differentiate into mature oligodendrocytes (for review, see Orentas and Miller, 1997; Rogister et al., 1999). Therefore, the analysis of cell cycle exit in OP cells is relevant to our understanding of oligodendrocyte development. We have used purified rat OP cells to investigate the molecular mechanisms that regulate permanent cell cycle withdrawal and reversible arrest in the oligodendrocyte lineage. Our findings demonstrate that distinct cyclin-cdk complexes are involved in reversible cell cycle arrest and permanent withdrawal in OP cells and that cyclin E-cdk2 and its associated activity is a major regulator of OP $\mathrm{G}_{1}-\mathrm{S}$ progression and decision to divide (Fig. 8).

Previous studies in cultured cells and in mutant mice have analyzed some of the cell cycle regulatory mechanisms in OP cells, with a focus on proteins involved in $\mathrm{G}_{1}-\mathrm{S}$ progression (Casaccia-Bonnefil et al., 1997, 1999; Durand et al., 1997, 1998; Tang et al., 1998; Ghiani et al., 1999a,b). One of the mechanisms that has received much attention involves the cdki $\mathrm{p} 27^{\mathrm{Kip} 1}$ and its binding to the cyclin E-cdk2 complex. Expression of $\mathrm{p} 27^{\mathrm{Kip} 1}$ is inversely correlated with the proliferative potential of OPs (Casaccia-Bonnefil et al., 1997; Durand et al., 1997; Ghiani et al., 1999a). Antiproliferative agents that cause reversible cell cycle arrest in $G_{1}$ phase stimulate p27 ${ }^{\mathrm{Kip} 1}$ accumulation in OP cells (Ghiani et al., 1999a,b), and p27 ${ }^{\mathrm{Kip} 1}$ is involved in cAMPinduced cell cycle withdrawal and differentiation of a glial cell line after cAMP treatment (Friessen et al., 1997).

The increase in $\mathrm{p} 27^{\mathrm{Kip} 1}$ protein levels observed during OP cell differentiation results in an enhancement of its binding to the cyclin E-cdk2 complex and inhibition of cdk2 activity (Tikoo et al., 1997; Tang et al., 1998). Ectopic expression of $\mathrm{p} 27^{\mathrm{Kip} 1}$ in OP cells causes a significant reduction in cyclin E-cdk2 activity and cell cycle arrest (Tikoo et al., 1998; Tang et al., 1999).

The aim of the present study was to determine whether, in 
A
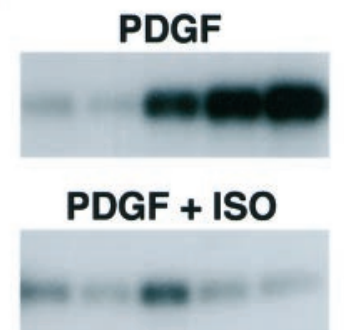

$\begin{array}{lllll}3 & 6 & 18 & 24 & 48\end{array}$

time (hr)

B

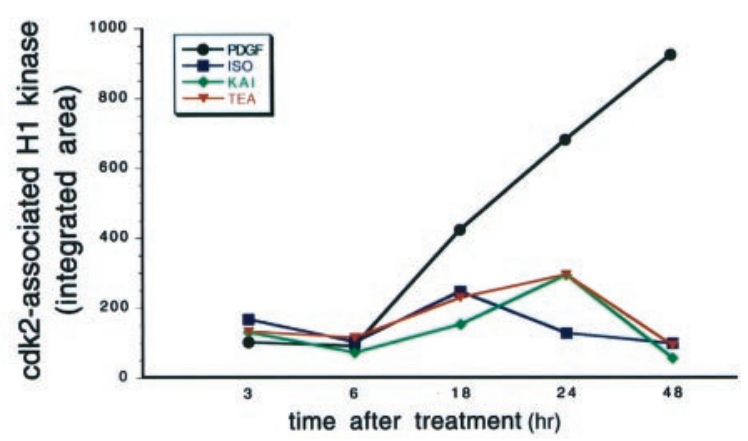

Figure 5. The time course of regulation of cyclin E-cdk2 activity is consistent with cell cycle arrest in $G_{1}$ phase. Newly plated OPs were cultured for a total of $2 \mathrm{~d}$ in PDGF, in the presence or in the absence of the $\beta$-AR agonist isoproterenol (iso; $50 \mu \mathrm{M}$ ), the GluR agonist kainate (kai; $100 \mu \mathrm{M})$, or the $\mathrm{K}^{+}$channel blocker TEA $(5 \mathrm{~mm})$. OP cells were harvested at different times after adding PDGF and the antiproliferative agents to the culture medium. Cdk2-associated kinase activity was determined after immunoprecipitation of $50 \mu \mathrm{g}$ of total cellular protein extracts with anti-cdk2 antibodies and by using histone $\mathrm{H} 1$ as a substrate. The plots represent relative levels of cdk2-associated activity, obtained by PhosphorImager analysis of the autoradiographs shown in $A$. Both $A$ and $B$ refer to a representative experiment that was replicated twice with similar results.

addition to $\mathrm{p} 27^{\mathrm{Kip} 1}$-mediated inhibition of cyclin E-cdk 2 activity, other mechanisms could regulate permanent cell cycle withdrawal and reversible arrest in OP cells. We analyzed the cyclins and cdks involved in $\mathrm{OP}_{1}-\mathrm{S}$ progression, in particular the formation and activity of cyclin D-cdk4/6 and cyclin E-cdk2. Our study indicates that experimental paradigms inducing either permanent cell cycle withdrawal or reversible arrest impaired the formation of these complexes and strongly affected their kinase activities.

Under all of the experimental conditions used, we observed a direct correlation between activity of a specific cdk and its ability to associate with its cyclin partner. All of the treatments that modified cdk2 and cyclin D-associated kinase activity also affected formation of the cyclin E-cdk2 and cyclin D-cdk4 complexes. Conversely, none of the antiproliferative agents that cause reversible $G_{1}$ arrest in OP cells decreased cyclin D-cdk4 or cyclin D-cdk6 complex formation and activity. Interestingly, we observed an increase in cyclin D-cdk4 complex formation after treatment of OP cells with agents that caused $\mathrm{G}_{1}$ arrest (Fig. 6B), possibly attributable to the increase in cyclin $\mathrm{D}$ protein levels under the same conditions (Fig. 1B) (Sherr and Roberts, 1999). However, these changes did not result in a significant increase in cyclin D-associated kinase activity (Fig. 2).
We also observed insignificant changes in cyclin D-cdk6 complex formation under any of the experimental conditions used, except after treatment of OP cells with T3 hormone (Fig. 6C). This finding suggests that the decrease in cyclin D-associated kinase activity observed after withdrawal of mitogenic factors and/or T3 treatment is mostly attributable to changes in cdk4 activity. This interpretation is supported by the decrease in the levels of cyclin D-associated cdk4 under the same experimental conditions.

Our analysis in OP cells indicates that changes in cyclin and cdk protein levels are not inevitably associated with altered cyclincdk complex formation and/or activity. For example, cyclin D and cdk6 protein levels decreased after mitogen withdrawal (Fig. 1A), but no parallel change in cyclin D-cdk6 complex assembly was observed, unless cells were also treated with T3 hormone (Fig. $6 C)$. Antiproliferative agents significantly increased cyclin D levels (Fig. $1 B$ ) without modifying cyclin D-cdk6 complex assembly (Fig. 6C). On the other hand, all of the agents that caused reversible $\mathrm{G}_{1}$ arrest in OP cells strongly prevented cyclin E-cdk2 complex formation (Fig. 6A), without affecting the relative levels of either protein (Fig. $1 B$ ). It can be concluded that, to assign specific roles to cdks and their cognate cyclins in cell cycle progression and to understand the relevant mechanisms of regulation, both cyclin-cdk complex formation and activity must be analyzed.

Cyclin E-cdk2 kinase activity plays a central role in the regulation of cell cycle progression in mammalian cells (Koff et al., 1992; Ohtsubo et al., 1995), including glia (Ghiani and Gallo, 1999; Tikoo et al., 2000). The present study shows that assembly and activity of this enzymatic complex are strongly reduced when OP cells are cultured under conditions that cause permanent cell cycle withdrawal or reversible arrest in $\mathrm{G}_{1}$ (Fig. 8). Activation and deactivation of this enzymatic complex occur with a time course that is consistent with the pivotal role of cyclin $E-c d k 2$ in $G_{1}-S$ transition in OPs, because a strong upregulation of this kinase was observed in quiescent cells within $18 \mathrm{hr}$ after treatment with mitogenic factors (Fig. 4). The differences in kinase activity observed between cells treated in PDGF and bFGF (Fig. 4) further support the notion that cyclin $\mathrm{E}-\mathrm{cdk} 2$ is a major regulator of OP cell cycle progression. The finding that $48 \mathrm{hr}$ after treatment with growth factors cyclin E-cdk2 activity is significantly lower in bFGF than in PDGF correlates well with previous studies showing that cells cultured in bFGF display an $\mathrm{O}^{+} /$ preoligodendrocyte phenotype and divide more slowly than A2B5 ${ }^{+} / \mathrm{NG}^{+}$OPs (Dubois-Dalcq, 1987; Gard and Pfeiffer, 1990).

The increase in the protein levels of the $G_{1}$ phase marker cyclin $\mathrm{D}$ caused by GluR and $\beta$-AR activation or blockage of $\mathrm{K}^{+}$ channels (Fig. $1 B$ ) is consistent with our previous reports showing that the same treatments caused an increase in the cdkis p $27^{\mathrm{Kip} 1}$ and $\mathrm{p} 21^{\mathrm{Cip} 1}$ and $\mathrm{G}_{1}$ arrest in OP cells (Ghiani et al., 1999a,b). Here we show that treatment with these agents also impaired the formation of the cyclin E-cdk2 complex (Fig. 6A) and strongly decreased its kinase activity (Fig. 3), indicating that this parallel mechanism is also in place to prevent OP cells from entering $\mathrm{S}$ phase (Fig. 8).

We have shown previously that the $\beta$-AR agonist isoproterenol inhibits OP cell proliferation and stimulates lineage progression (Ghiani et al., 1999a). In the present study, we demonstrate that the mechanism of action of isoproterenol is different from that of constitutive maturation triggered by withdrawal of mitogenic factors. In OPs cultured in N1 medium with or without T3 hormone, 
A

IP: cyclin E WB: cdk2

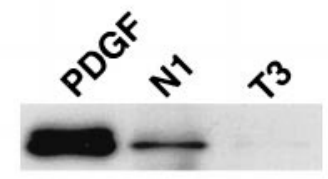

IP: cyclin D WB: cdk4
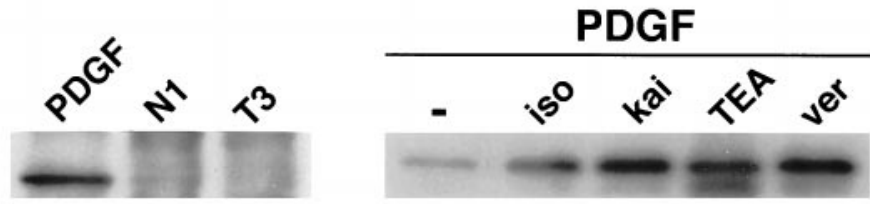

IP: cyclin D WB: cdk6

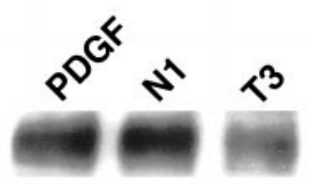

Figure 6. The decrease in cyclin E-cdk2 activity is associated to inhibition of cyclin E-cdk2 complex formation. Left panels, OP cells were cultured for $2 \mathrm{~d}$ in PDGF $(10 \mathrm{ng} / \mathrm{ml})$, followed by $3 \mathrm{~d}$ in N1 plus $0.5 \%$ FBS medium or N1 plus T3 $(100 \mathrm{ng} / \mathrm{ml})$ hormone medium to promote differentiation to oligodendrocytes. Right panels, Newly plated OP cells were cultured for $2 \mathrm{~d}$ with PDGF in the presence or in the absence of the $\beta$-AR agonist isoproterenol (iso; 50 $\mu \mathrm{M})$, the GluR agonist kainate (kai; $100 \mu \mathrm{M})$, the $\mathrm{K}^{+}$ channel blocker TEA $(5 \mathrm{mM})$, or the $\mathrm{Na}^{+}$channel opener veratridine $($ ver $; 30 \mu \mathrm{M})$. Cell extracts $(200 \mu \mathrm{g})$ were immunoprecipitated with anti-cyclin $\mathrm{E}(A)$ or cyclin $\mathrm{D}(B, C)$ antibodies, followed by Western blot analysis with anti-cdk2 $(A), \operatorname{cdk} 4(B)$, or cdk6 $(C)$ antibodies to determine the amount of cdk associated to their respective cyclin. The experiments shown were repeated twice. the protein levels of the major $\mathrm{G}_{1}-\mathrm{S}$ cdks were strongly decreased (Fig. 1A), whereas in cells treated with isoproterenol no change was observed (Fig. $1 B$ ). These differences are probably related to previous observations that the effects of isoproterenol were reversible (Ghiani et al., 1999a), whereas OPs that were cultured without mitogenic factors had irreversibly withdrawn from the cell cycle.

Isoproterenol causes a strong increase in intracellular cAMP levels in OP cells (Ghiani et al., 1999a); however, the mechanism of cell cycle arrest induced by $\beta$-AR agonist appears to be distinct from that described previously for cAMP in macrophages because of an inhibition of cdk4 activity (Kato et al., 1994). In contrast, isoproterenol did not modify cyclin D-associated kinase activity (Fig. 2) or phopshorylation of the cdk4 substrate $\mathrm{pRb}$ in OP cells (Ghiani and Gallo, data not shown).

Our findings in cultured OPs are consistent with the analysis of $\mathrm{G}_{1}-\mathrm{S}$ regulatory proteins performed in white matter in vivo. In corpus callosum, both cdk2 and cyclin E levels, as well as cyclin E-cdk2 activity, decreased between P15 and P30 (Fig. 7), i.e., during and after terminal division and differentiation of immature oligodendrocytes. The increase in cyclin E-cdk2 activity observed between P3 and P15 most likely reflects the final rounds of division of immature oligodendrocytes in this brain area and, interestingly, occurs without significant changes in cyclin $\mathrm{E}$ and cdk2 protein levels. In contrast to cultured OPs, however, we observed no change in cyclin D levels in corpus callosum during development. The reason for this difference is not yet clear; however, a downregulation of cyclin $\mathrm{D}$ was observed in optic nerve during postnatal development (data not shown).

Recent studies have shown the presence of anatomical contacts between neurons and OPs or immature oligodendrocytes in the developing brain. Functional synaptic contacts between glutamatergic terminals and immature oligodendrocytes have been dem-

\section{P3 P10 P15 P30}

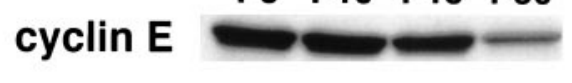

Cyclin D $2=-\infty$

\section{P3 P10 P15 P30}

cdk2

cdk4

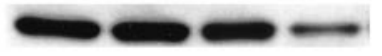

cdk6
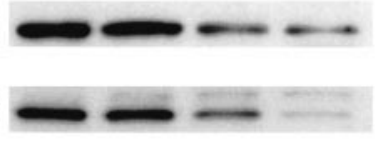

B

\section{P3 P10 P15 P30}

\section{Cdk2-associated H1 kinase}

Figure 7. $\mathrm{Cdk} 2$ and cyclin E protein levels and cyclin E-cdk2 activity decrease in corpus callosum during development in vivo. A, Expression of cyclin E, cyclin D, and cdk2 decreases between P15 and P30 in corpus callosum tissue extracts. The levels of cdk4 and cdk6 decrease between $\mathrm{P} 10$ and P30. Western blot analysis was performed by loading $30 \mu \mathrm{g}$ of tissue lysate for each sample. $B$, Changes in cyclin E-cdk2 activity in corpus callosum tissue extracts during development. Note the progressive increase in cdk2-associated activity between P3 and P15 and the decrease by $\mathrm{P} 30$. Cdk2-associated kinase activity was determined after immunoprecipitation of $50 \mu \mathrm{g}$ of tissue extracts with anti-cdk 2 antibodies and by using histone $\mathrm{H} 1$ as a substrate. 


\section{Cyclin E - Cdk2 Complex}

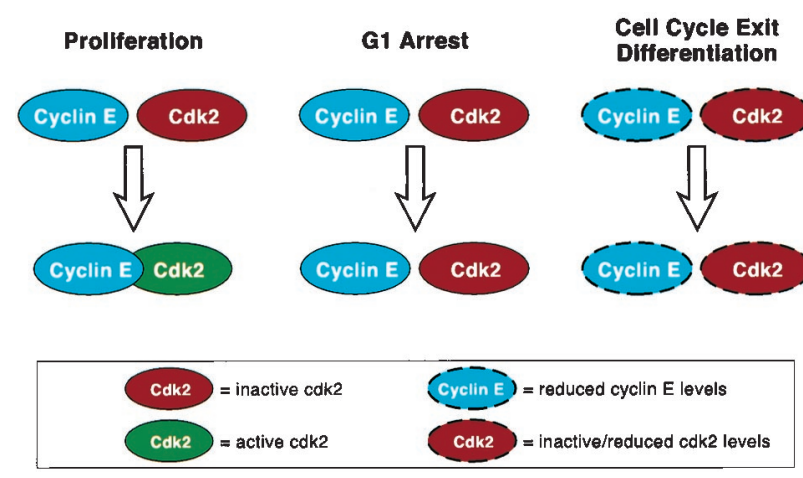

Figure 8. The cyclin E-cdk2 complex is a major regulator of $\mathrm{G}_{1}-\mathrm{S}$ transition in OP cells. Summary scheme describing the cyclin E-cdk2 interactions involved in cell cycle withdrawal and arrest in OP cells. Dotted lines indicate decreased levels of the protein. Red and green refer to inactive and active kinase, respectively.

onstrated in the hippocampus (Bergles et al., 2000). In the visual cortex, noradrenergic terminals make direct synaptic contacts with oligodendrocytes (Paspalas and Papadopoulos, 1996). It appears, therefore, that OPs and immature oligodendrocytes can receive glutamatergic and noradrenergic signals from neurons in vivo, which might affect $\mathrm{OP}$ cell cycle progression and differentiation (Gallo and Ghiani, 2000; Gallo et al., 2001). The present study describes some of the cell cycle proteins targeted by these neuronal signals.

In conclusion, our study not only identifies the major cell cycle components involved in the regulation of OP proliferation, cell cycle arrest, and withdrawal, but also has important implications for our understanding of how physiological signals modulate OP development in vivo.

\section{REFERENCES}

Bergles DE, Roberts JDB, Somogyi P, Jahr CE (2000) Glutamatergic synapses on oligodendrocyte precursor cells in the hippocampus. Nature 405:187-191.

Casaccia-Bonnefil P, Tikoo R, Kiyokawa H, Friederich Jr V, Chao MV, Koff A (1997) Oligodendrocyte precursor differentiation is perturbed in the absence of the cyclin-dependent kinase inhibitor p2 $7^{\mathrm{K} i \mathrm{p} 1}$. Genes Dev 11:2335-2346.

Casaccia-Bonnefil P, Hardy RJ, Teng KK, Levine JM, Koff A, Chao MV (1999) Loss of p27Kip1 function results in increased proliferative capacity of oligodendrocyte progenitors but unaltered timing of differentiation. Development 126:4027-4037.

Dubois-Dalcq M (1987) Characterization of a slowly proliferative cell along the oligodendrocyte differentiation pathway. EMBO J 6:2587-2595.

Durand B, Gao F-B, Raff M (1997) Accumulation of the cyclindependent kinase inhibitor p27/kip1 and the timing of oligodendrocyte differentiation. EMBO J 16:306-317.

Durand B, Fero ML, Roberts JM, Raff MC (1998) p27 Kip1 alters the response of cells to mitogen and is part of a cell-intrinsic timer that arrests the cell cycle and initiates differentiation. Curr Biol 8:431-440.

Edlund T, Jessell TM (1999) Progression from extrinsic to intrinsic signaling in cell fate specification: a view from the nervous system. Cell 96:211-224.

Elledge SJ (1996) Cell cycle checkpoints: preventing an identity crisis. Science 274:1664-1672.

Friessen AJ, Miskimins WK, Miskimins R (1997) Cyclin-dependent kinase inhibitor $\mathrm{p} 27^{\mathrm{Kipl}}$ is expressed at high levels in cells that express a myelinating phenotype. J Neurosci Res 50:373-382.

Gallo V, Armstrong R (1995) Developmental and growth factor induced regulation of nestin in oligodendrocyte lineage cells. J Neurosci $15: 394-406$

Gallo V, Ghiani CA (2000) Glutamatergic receptors in glia: new cells, new inputs and new functions. Trends Pharmacol Sci 21:252-258.

Gallo V, Zhou JM, McBain CJ, Wright PW, Knutson PL, Armstrong R (1996) Oligodendrocyte progenitor cell proliferation and lineage pro- gression are regulated by glutamate receptor-mediated $\mathrm{K}^{+}$channel block. J Neurosci 16:2659-2670.

Gallo V, Ghiani CA, Yuan X (2001) The role of ion channels and neurotransmitter receptors in glial cell development. In: Glial cell development (Jessen KR, Richardson WD, eds). New York: Oxford UP, in press.

Gard AL, Pfeiffer SE (1990) Two proliferative stages of the oligodendrocyte lineage (A2B5 ${ }^{+} \mathrm{O} 4{ }^{-}$and $\left.\mathrm{O}^{+}{ }^{+} \mathrm{GalC}^{-}\right)$under different mitogenic control. Neuron 17:1397-1405.

Ghiani CA, Gallo V (1999) Neurotransmitter receptor activation and blockage of $\mathrm{K}^{+}$channels inhibit cyclin-dependent kinase activity in oligodendrocyte progenitor cells. Soc Neurosci Abstr 25:204.

Ghiani CA, Eisen AM, Yuan X, DePinho RA, McBain CJ, Gallo V (1999a) Neurotransmitter receptor activation triggers $\mathrm{p} 27^{\mathrm{Kip} 1}$ and p21 ${ }^{\mathrm{CIP} 1}$ accumulation and $\mathrm{G}_{1}$ cell cycle arrest in oligodendrocyte progenitors. Development 126:1077-1090.

Ghiani CA, Yuan X, Eisen AM, Knutson PL, DePinho RA, McBain CJ, Gallo V (1999b) Voltage-activated $\mathrm{K}^{+}$channels and membrane depolarization regulate accumulation of the cyclin-dependent kinase inhibitors $\mathrm{p} 27^{\mathrm{Kip} 1}$ and $\mathrm{p} 21^{\mathrm{CIP} 1}$ in glial progenitor cells. J Neurosci 19:5380-5392.

Gong Q, Shipley MT (1995) Evidence that pioneer olfactory axons regulate telencephalon cell cycle kinetics to induce the formation of the olfactory bulb. Neuron 14:91-101.

Hunter T (1993) Braking the cycle. Cell 75:839-841.

Kato J, Matsuoka M, Polyak K, Massague J, Sherr CJ (1994) Cyclic AMP-induced G1 phase arrest mediated by an inhibitor (p27 $\left.{ }^{\mathrm{Kip} 1}\right)$ of cyclin-dependent kinase 4 activation. Cell 79:487-496.

Koff A, Giordano A, Desai D, Yamashita K, Harper JW, Eledge S, Nishimoto T, Morgan DO, Franza BR, Roberts JM (1992) Formation and activation of a cyclin E-cdk2 complex during the G1 phase of the human cell cycle. Science 257:1689-1694.

Koff A, Ohtsuki M, Polyak K, Roberts JM, Massague J (1993) Negative regulation of G1 in mammalian cells: inhibition of cyclin E-dependent kinase by TGF-beta. Science 260:536-539.

Levison SW, Goldman JE (1993) Both oligodendrocytes and astrocytes develop from progenitors in the subventricular zone of postnatal rat forebrain. Neuron 10:201-212.

Luskin MB, McDermott K (1994) Divergent lineages for oligodendrocytes and astrocytes originating in the neonatal forebrain subventricular zone. Glia 7:9-18.

Martin-Castellanos C, Moreno S (1997) Recent advances on cyclins, CDKs and CDK inhibitors. Trends Cell Biol 7:95-98.

Matsushime H, Quelle DE, Shurtleff SA, Shibuya M, Sherr CJ, Kato J-Y (1994) D-type cyclin-dependent kinase activity in mammalian cells. Mol Cell Biol 14:2066-2076.

McCarthy KD, deVellis J (1980) Preparation of separate astroglial and oligodendroglia cell cultures from rat cerebral tissue. J Cell Biol 85:890-902.

Morgan DO (1995) Principles of CDK regulation. Nature 374:131-134.

Ohtsubo M, Theodoras AM, Schumacher J, Roberts JM, Pagano M (1995) Human cyclin E, a nuclear protein essential for the G1-to-S phase transition. Mol Cell Biol 15:2612-2624.

Orentas DM, Miller RH (1997) Regulation of oligodendrocyte development. Mol Neurosci 18:247-257.

Pardee A (1989) G1 events and regulation of cell proliferation and differentiation. Science 24:603-608.

Paspalas CD, Papadopoulos GC (1996) Ultrastructural relationships between noradrenergic nerve fibers and non-neuronal elements in the rat cerebral cortex. Glia 17:133-146.

Pedram A, Razandi M, Hu R-M, Levin ER (1998) Astrocyte progression from $G_{1}$ to $S$ phase of the cell cycle depends upon multiple protein interaction. J Biol Chem 273:13966-13972.

Perez-Juste G, Aranda A (1999) The cyclin-dependent kinase inhibitor $\mathrm{p} 27^{\mathrm{Kip} 1}$ is involved in thyroid hormone-mediated neuronal differentiation. J Biol Chem 274:5026-5031.

Purves D (1988) Body and brain: a trophic theory of neural connections. Cambridge, MA: Harvard UP.

Raff MC (1996) Size control: the regulation of cell numbers in animal development. Cell 86:173-175.

Raff MC, Miller RH, Noble M (1983) A glial progenitor cell that develops in vitro into an astrocyte or an oligodendrocyte depending on culture medium. Nature 303:390-396.

Reed SI, Bailly E, Dulic V, Hengst L, Resnitzky D, Slingerland J (1994) G1 control in mammalian cells. J Cell Sci [Suppl] 18: 69-73.

Reynolds R, Wilkin GP (1988) Development of macroglial cells in rat cerebellum. II. An in situ immunohistochemical study of oligodendroglial lineage from precursor to mature myelinating cell. Development 102:409-425.

Rogister B, Ben-Hur T, Dubois-Dalcq M (1999) From neural stem cells to myelinating oligodendrocytes. Mol Cell Neurosci 14:287-300.

Ross ME (1996) Cell division and the nervous system: regulating the cycle from neural differentiation to death. Trends Neurosci 19:62-68.

Selleck SB, Gonzalez C, Glover DM, White K (1992) Regulation of the 
G1-S transition in postembryonic neuronal precursors by axon ingrowth. Nature 355:253-255.

Sherr CJ (1994) G1 phase progression: cycling on cue. Cell 79:551-555. Sherr CJ (1995) D-Type cyclins. Trends Biol Sci 20:187-190.

Sherr CJ, Roberts JM (1995) Inhibitors of mammalian $\mathrm{G}_{1}$ cyclindependent kinases. Genes Dev 9:1149-1163.

Sherr CJ, Roberts JM (1999) CDK inhibitors: positive and negative regulators of $\mathrm{G}_{1}$-phase progression. Genes Dev 13:1501-1512.

Tang XM, Strocchi P, Cambi F (1998) Changes in the activations of cdk 2 and cdk5 accompany differentiation of rat primary oligodendrocytes. J Cell Biochem 68:128-137.

Tang XM, Beesley JS, Grinspan JB, Seth P, Kamholz J, Cambi F (1999) Cell cycle arrest induced by ectopic expression of $\mathrm{p} 27$ is not sufficient to promote oligodendrocyte differentiation. J Cell Biochem 76:270-279.
Tikoo R, Casaccia-Bonnefil P, Chao MV, Koff A (1997) Changes in cyclin-dependent kinase 2 and $\mathrm{p} 27^{\mathrm{Kip} 1}$ accompany glial cell differentiation of central glia-4 cells. J Biol Chem 272:442-447.

Tikoo R, Osterhout DJ, Casaccia-Bonnefil P, Seth P, Koff A, Chao MV (1998) Ectopic expression of $\mathrm{p} 27^{\mathrm{Kip} 1}$ in oligodendrocyte progenitor cells results in cell-cycle growth arrest. J Neurobiol 36:431-440.

Tikoo R, Zanazzi G, Shiffman D, Salzer J, Chao MV (2000) Cell cycle control of Schwann cell proliferation; role of cyclin-dependent kinase-2. J Neurosci 20:4627-4634.

Weinberg RA (1995) The retinoblastoma protein and cell cycle control. Cell 81:323-330.

Zerlin M, Levison S, Goldman JE (1995) Early patterns of migration, morphogenesis, and intermediate filament expression of subventricular zone cells in the postnatal rat forebrain. J Neurosci 15:7238-7249. 